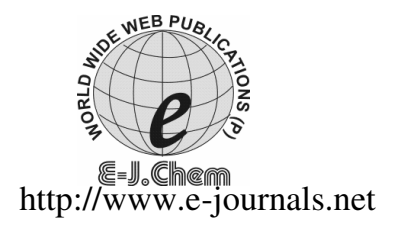

ISSN: 0973-4945; CODEN ECJHAO

E-Journal of Chemistry 2010, 7(1), 123-136

\title{
Synthesis and In Vitro Antioxidant Evaluation of Some Novel 4, 5-Dihydro-1H-1, 2, 4-triazol-5-one Derivatives
}

\author{
O. GURSOY KOL and H. YUKSEK \\ Department of Chemistry, \\ Kafkas University, 36100 Kars, Turkey. \\ hyuksek98@yahoo.com
}

Received 1 July 2009; Accepted 1 September 2009

\begin{abstract}
In this study, thirteen novel 4,5-dihydro-1 $H$-1,2,4-triazol-5-one derivatives were synthesized and characterized by elemental analyses and IR, ${ }^{1} \mathrm{H}$ NMR, ${ }^{13} \mathrm{C}$ NMR and UV spectral data. The synthesized compounds were analyzed for their in vitro potential antioxidant activities in three different methods. Those antioxidant activities were compared to standard antioxidants such as BHA, BHT and $\alpha$-tocopherol. The data reveal that the compounds demonstrate a marked capacity for iron binding, especially 5a and 7c. In addition to this, the compounds 4 were titrated potentiometrically with TBAH in non-aqueous solvents because of the weak acidic properties of 4,5-dihydro$1 H$-1,2,4-triazol-5-one ring $\mathrm{N}-\mathrm{H}$ group.
\end{abstract}

Keywords: 1,2,4-Triazol-5-one, Schiff base, Synthesis, Antioxidant activity, Acidity.

\section{Introduction}

Compounds containing 1,2,4-triazole ring have been reported to possess different biological activities such as antimicrobial, antifungal, anti-inflammatory, antioxidant, antiviral, anticancer, analgesic, and anticonvulsant activity depending on the substituents in the ring system $^{1-9}$. Moreover several articles reporting the synthesis of some $\mathrm{N}$-arylidenamino-4,5dihydro-1H-1,2,4-triazol-5-one derivatives have been published ${ }^{5,10-14}$.

Besides, antioxidants have become one of the major areas of scientific research. Antioxidants are extensively studied for their capacity to protect organism and cell from damage that are induced by oxidative stress. Scientists in many different disciplines become more interested in new compounds, either synthesized or obtained from natural sources that could provide active components to prevent or reduce the impact of oxidative stress on cell ${ }^{15}$. Exogenous chemicals and endogenous metabolic processes in human body or in food system might produce highly reactive free radicals, especially oxygen derived radicals, which are capable of oxidizing biomolecules, resulting in cell death and issue damage. Oxidative damages 
play a significantly pathological role in human diseases. Cancer, emphysema, cirrhosis, atherosclerosis and arthritis have all been correlated with oxidative damage. Also, excessive generation of reactive oxygen species (ROS) induced by various stimuli and which exceeds the antioxidant capacity of the organism leads to variety of pathophysiological processes such as inflammation, diabetes, genotoxicity and cancer $^{16}$. In the present study, due to a wide range applications and to find their possible radical scavenging and antioxidant activity, the newly synthesized compounds were investigated using different antioxidant methodologies: 1,1diphenyl-2-picryl-hydrazyl (DPPH) free radical scavenging, reducing power and metal chelating activities.

On the other hand, it is known that 1,2,4-triazole and 4,5-dihydro- $1 \mathrm{H}$-1,2,4-triazol-5-one rings have weak acidic properties, therefore, some 1,2,4-triazole and 4,5-dihydro- $1 \mathrm{H}-1,2,4$ triazol-5-one derivatives were titrated potentiometrically with tetrabutylammonium hydroxide (TBAH) in non-aqueous solvents and the $\mathrm{pK}_{\mathrm{a}}$ values of the compounds were determined $^{5,10-13,17,18}$.

\section{Experimental}

Chemical reagents and all solvents used in this study were purchased from Merck AG, Aldrich and Fluka. The starting materials (2a-g) were prepared from the reactions of the corresponding ester ethoxycarbonylhydrazones (1a-g) with an aqueous solution of hydrazine hydrate as described in the literature ${ }^{14,19}$. Melting points were determined in open glass capillaries using an Electrothermal 9100 digital melting point apparatus and are uncorrected. The IR spectra were obtained on a Perkin-Elmer Instruments Spectrum One FT-IR spectrometer. ${ }^{1} \mathrm{H}$ NMR and ${ }^{13} \mathrm{C}$ NMR spectra were recorded in deuterated dimethyl sulfoxide with TMS as internal standard using a Varian Mercury spectrometer at $200 \mathrm{MHz}$ and $50 \mathrm{MHz}$, respectively. UV absorption spectra were measured in $10 \mathrm{~mm}$ quartz cells between 200 and $400 \mathrm{~nm}$ using a Schimadzu-1201 UV/VIS spectrometer. Extinction coefficients $(\varepsilon)$ are expressed in $\mathrm{L} \mathrm{mol}^{-}$ ${ }^{1} \cdot \mathrm{cm}^{-1}$. Elemental analyses were carried out on an ECS 4010 Costech Instruments Elemental Combustion System (CHNS-O) for C, H, and N. Butylated hydroxytoluene (BHT) was purchased from E. Merck. Ferrous chloride, $\alpha$-tocopherol, 1,1-diphenyl-2-picryl-hydrazyl (DPPH), 3-(2-pyridyl)-5,6-bis(phenylsulfonic acid)-1,2,4-triazine (ferrozine), butylated hydroxyanisole (BHA) and trichloracetic acid (TCA) were bought from Sigma.

\section{General procedure for the synthesis of compounds 4}

3-Hydroxybenzaldehyde $(0.01 \mathrm{~mol})$ was dissolved in ethyl acetate $(15 \mathrm{~mL})$ was treated with 4 nitrobenzoyl chloride $(0.01 \mathrm{~mol})$ and to this solution was added triethylamine $(0.01 \mathrm{~mol})$ slowly with stirring at $0-5{ }^{\circ} \mathrm{C}$. Stirring was continued for $2 \mathrm{~h}$, then the mixture was refluxed for $4 \mathrm{~h}$ and filtered. The filtrate was evaporated in vacuo and the crude product was washed with water and recrystallized from ethanol to afford compound 3, m.p. $133^{\circ} \mathrm{C}$; IR $(\mathrm{KBr})\left(v, \mathrm{~cm}^{-1}\right)$ : CHO 2854, 2752; $\mathrm{C}=\mathrm{O} 1727,1699 ; \mathrm{NO}_{2} 1525$ and 1350; $\mathrm{COO} 1235,1,3$-disubstituted benzenoid ring 778 and 712 . The corresponding compound $2(0.01 \mathrm{~mol})$ was dissolved in acetic acid $(15 \mathrm{~mL})$ and treated with 3-(4-nitrobenzoxy)benzaldehyde (3) $(0.01 \mathrm{~mol})$. The mixture was refluxed for $1.5 \mathrm{~h}$ and then evaporated at $50-55^{\circ} \mathrm{C}$ in vacuo. Several recrystallizations of the residue from $\mathrm{AcOH}-$ $\mathrm{H}_{2} \mathrm{O}$ (1:3) gave pure compounds (4) as colorless crystals.

\section{3-Methyl-4-[3-(4-nitrobenzoxy)benzylidenamino]-4,5-dihydro-1H-1,2,4-triazol- 5-one $(\mathbf{4 a})$}

Yield 2.81 g (96\%). M.p. $270{ }^{\circ} \mathrm{C}$. IR (KBr): NH 3178; C=O 1748, 1703; C=N 1607, 1577; $\mathrm{NO}_{2} 1525$ and 1347; COO 1261; 1, 4-disubstituted benzenoid ring 842; 1, 3- disubstituted 
benzenoid ring 798 and $714 \mathrm{~cm}^{-1} .{ }^{1} \mathrm{H}$ NMR (DMSO-d $\left.\mathrm{d}_{6}\right): \delta 2.24\left(\mathrm{~s}, 3 \mathrm{H}, \mathrm{CH}_{3}\right), 7.43-7.77(\mathrm{~m}, 4 \mathrm{H}$, Ar-H), 8.28-8.38 (m, 4H, Ar-H), $9.72(\mathrm{~s}, 1 \mathrm{H}, \mathrm{N}=\mathrm{CH}), 11.82(\mathrm{~s}, 1 \mathrm{H}, \mathrm{NH}) .{ }^{13} \mathrm{C}$ NMR (DMSO-d 6 ): $\delta 10.91\left(\mathrm{CH}_{3}\right), 119.92,123.77(2 \mathrm{C}), 124.58,126.04,130.16,131.16(2 \mathrm{C}), 134.11,135.18$, 150.66, 151.04 (arom-C), 144.17 (triazole $\left.\mathrm{C}_{3}\right), 150.39(\mathrm{~N}=\mathrm{CH}), 152.01$ (triazole $\mathrm{C}_{5}$ ), 162.93 $(\mathrm{C}=\mathrm{O})$. UV $\lambda_{\max }(\varepsilon): 256$ (4488), $209(17049) \mathrm{nm}$. Anal. Calcd. for $\mathrm{C}_{17} \mathrm{H}_{13} \mathrm{~N}_{5} \mathrm{O}_{5}$ (367.32): C, 55.59; H, 3.57; N, 19.07. Found: C, 55.65; H, 3.77; N, 19.06.

3-Ethyl-4-[3-(4-nitrobenzoxy)benzylidenamino]-4,5-dihydro-1H-1,2,4-triazol-5-one (4b) Yield 2.41 g (63\%). M p. $226{ }^{\circ} \mathrm{C}$. IR (KBr): NH 3178; C=O 1736, 1705; C=N 1607, 1592; $\mathrm{NO}_{2} 1527$ and 1349; COO 1263; 1,4-disubstituted benzenoid ring 842; 1,3-disubstituted benzenoid ring 793 and $713 \mathrm{~cm}^{-1} .{ }^{1} \mathrm{H}$ NMR (DMSO-d $\left.)_{6}\right): \delta 1.17\left(\mathrm{t}, 3 \mathrm{H}, \mathrm{CH}_{3}\right), 2.64(\mathrm{q}, 2 \mathrm{H}$, $\mathrm{CH}_{2}$ ), 7.44-7.76 (m, 4H, Ar-H), 8.29-8.39 (m, 4H, Ar-H), $9.72(\mathrm{~s}, 1 \mathrm{H}, \mathrm{N}=\mathrm{CH}), 11.84(\mathrm{~s}, 1 \mathrm{H}$, $\mathrm{NH}) .{ }^{13} \mathrm{C}$ NMR (DMSO-d $): \delta 9.80\left(\mathrm{CH}_{3}\right), 18.32\left(\mathrm{CH}_{2}\right), 119.96,123.79(2 \mathrm{C}), 124.59$, 125.96, 130.19, 131.19 (2C), 134.14, 135.21, 150.69, 151.21 (arom-C), 147.91 (triazole $\mathrm{C}_{3}$ ), $150.42(\mathrm{~N}=\mathrm{CH}), 152.12$ (triazole $\mathrm{C}_{5}$ ), $162.94(\mathrm{C}=\mathrm{O}) . \mathrm{UV} \lambda_{\max }(\varepsilon)$ : $256(19476), 213(22229) \mathrm{nm}$.

3-Benzyl-4-[3-(4-nitrobenzoxy)benzylidenamino]-4,5-dihydro-1H-1,2,4-triazol-5-one (4c) Yield 4.35 g (98\%). M.p. $216^{\circ} \mathrm{C}$. IR (KBr): NH 3164; C=O 1745, 1714; C=N 1591; $\mathrm{NO}_{2} 1522$ and 1349; COO 1266; 1,4-disubstituted benzenoid ring 823; 1,3-disubstituted benzenoid ring 784 and $713 \mathrm{~cm}^{-1}$; monosubstituted benzenoid ring 760 and $688 \mathrm{~cm}^{-1} .{ }^{1} \mathrm{H}$ NMR (DMSO-d $\mathrm{d}_{6}$ ): $\delta$ 4.04 (s, 2H, $\mathrm{CH}_{2}$ ), 7.16-7.32 (m, 5H, Ar-H), 7.44-7.73 (m, 4H, Ar-H), 8.34-8.43 (m, 4H, Ar$\mathrm{H}), 9.70(\mathrm{~s}, 1 \mathrm{H}, \mathrm{N}=\mathrm{CH}), 12.00(\mathrm{~s}, 1 \mathrm{H}, \mathrm{NH}) .{ }^{13} \mathrm{C}$ NMR (DMSO-d $): \delta 30.98\left(\mathrm{CH}_{2}\right), 120.12$, 123.90 (2C), 124.59, 126.00, 126.59, 128.30 (2C), 128.72 (2C), 130.24, 131.23 (2C), 134.17, 135.16, 135.62, 150.66, 151.05 (arom-C), 146.15 (triazole $\left.\mathrm{C}_{3}\right), 150.51(\mathrm{~N}=\mathrm{CH}), 151.91$ (triazole $\mathrm{C}_{5}$ ), $162.97(\mathrm{C}=\mathrm{O})$. UV $\lambda_{\max }(\varepsilon)$ : 258 (9254), 212 (14492) nm.

3-p-Methylbenzyl-4-[3-(4-nitrobenzoxy)benzylidenamino]-4,5-dihydro-1H-1,2,4-triazol5-one $(\mathbf{4 d})$

Yield 3.31 g (73\%). M.p. $229^{\circ} \mathrm{C}$. IR (KBr): NH 3175; C=O 1747, 1713; C=N 1589, 1576; $\mathrm{NO}_{2} 1523$ and 1352; COO 1266; 1,4-disubstituted benzenoid ring 840, 819; 1,3disubstituted benzenoid ring 785 and $714 \mathrm{~cm}^{-1} .{ }^{1} \mathrm{H}$ NMR (DMSO-d 6 ): $\delta 2.17\left(\mathrm{~s}, 3 \mathrm{H}, \mathrm{CH}_{3}\right.$ ), $3.97\left(\mathrm{~s}, 2 \mathrm{H}, \mathrm{CH}_{2}\right), 7.03$ (d, 2H, Ar-H, J=8.06 Hz), $7.16(\mathrm{~d}, 2 \mathrm{H}, \mathrm{Ar}-\mathrm{H}, \mathrm{J}=8.09 \mathrm{~Hz}), 7.44-7.72$ $(\mathrm{m}, 4 \mathrm{H}, \mathrm{Ar}-\mathrm{H}), 8.32-8.42(\mathrm{~m}, 4 \mathrm{H}, \mathrm{Ar}-\mathrm{H}), 9.68(\mathrm{~s}, 1 \mathrm{H}, \mathrm{N}=\mathrm{CH}), 11.97(\mathrm{~s}, 1 \mathrm{H}, \mathrm{NH}) .{ }^{13} \mathrm{C} \mathrm{NMR}$ $\left(\right.$ DMSO-d $\left._{6}\right): \delta 20.42\left(\mathrm{CH}_{3}\right), 30.58\left(\mathrm{CH}_{2}\right), 120.06,123.86(2 \mathrm{C}), 124.54,125.99,128.56(2 \mathrm{C})$, 128.83 (2C), 130.21, 131.20 (2C), 132.47, 134.14, 135.17, 135.62, 150.64, 151.04 (arom-C), 144.26 (triazole $\mathrm{C}_{3}$ ), $150.49(\mathrm{~N}=\mathrm{CH}), 151.86$ (triazole $\mathrm{C}_{5}$ ), $162.94(\mathrm{C}=\mathrm{O})$. UV $\lambda_{\max }(\varepsilon): 257$ (20261), 264 (7550), 214 (27364) nm. Anal. Calcd. for $\mathrm{C}_{24} \mathrm{H}_{19} \mathrm{~N}_{5} \mathrm{O}_{5}$ (457.45): C, 63.02; H, 4.19; N, 15.31. Found: C, 62.94; H, 4.97; N, 15.41 .

3-p-Chlorobenzyl-4-[3-(4-nitrobenzoxy)benzylidenamino]-4,5-dihydro-1H-1,2,4triazol-5-one $(\mathbf{4 e})$

Yield 4.65 g (97\%). M.p. $219{ }^{\circ} \mathrm{C}$. IR (KBr): NH 3173; C=O 1744, 1716; C=N 1591, 1575; $\mathrm{NO}_{2} 1525$ and 1354; $\mathrm{COO}$ 1264; 1,4-disubstituted benzenoid ring 829, 810; 1,3disubstituted benzenoid ring 794 and $713 \mathrm{~cm}^{-1} .{ }^{1} \mathrm{H}$ NMR (DMSO-d 6 ): $\delta 4,04\left(\mathrm{~s}, 2 \mathrm{H}, \mathrm{CH}_{2}\right.$ ), 7.30-7.33 (m, 4H, Ar-H), 7.48-7.73 (m, 4H, Ar-H), 8.37-8.43 (m, 4H, Ar-H), 9.60 (s, 1H, $\mathrm{N}=\mathrm{CH}), 12.01(\mathrm{~s}, 1 \mathrm{H}, \mathrm{NH}) .{ }^{13} \mathrm{C}$ NMR $\left(\mathrm{DMSO}-\mathrm{d}_{6}\right): \delta 30.31\left(\mathrm{CH}_{3}\right), 120.05,123.86(2 \mathrm{C})$, 124.62, 126.08, 128.20 (2C), 130.25, 130.66 (3C), 131.23 (2C), 134.17, 134.56, 135.10, 150.66, 151.02 (arom-C), 145.80 (triazole $\left.\mathrm{C}_{3}\right), 150.49(\mathrm{~N}=\mathrm{CH}), 151.95$ (triazole $\mathrm{C}_{5}$ ), 162.97 $(\mathrm{C}=\mathrm{O}) . \mathrm{UV} \lambda_{\max }(\varepsilon): 258(13520), 214(22700) \mathrm{nm}$. 
3-Phenyl-4-[3-(4-nitrobenzoxy)benzylidenamino]-4,5-dihydro-1H-1,2,4-triazol-5-one (4f) Yield 3.71 g (86\%). M.p. $247^{\circ} \mathrm{C}$. IR (KBr): NH 3159; C=O 1736, 1707; C=N 1607, 1577; $\mathrm{NO}_{2} 1526$ and 1351; COO 1264; 1,4-disubstituted benzenoid ring 841; 1,3-disubstituted benzenoid ring 803 and $712 \mathrm{~cm}^{-1}$; monosubstituted benzenoid ring 771 and $695 \mathrm{~cm}^{-1} .{ }^{1} \mathrm{H}$ NMR (DMSO-d $\left.\mathrm{d}_{6}\right): \delta$ 7.45-7.86 $(\mathrm{m}, 9 \mathrm{H}, \mathrm{Ar}-\mathrm{H}), 8.26-8.36(\mathrm{~m}, 4 \mathrm{H}, \mathrm{Ar}-\mathrm{H}), 9.67(\mathrm{~s}, 1 \mathrm{H}$, $\mathrm{N}=\mathrm{CH}), 12.39(\mathrm{~s}, 1 \mathrm{H}, \mathrm{NH}) .{ }^{13} \mathrm{C}$ NMR $\left(\mathrm{DMSO}_{-} \mathrm{d}_{6}\right): \delta 120.60,123.75(2 \mathrm{C}), 124.78,125.72$, $126.39,127.80$ (2C), 128.37 (2C), 129.97, 130.26, 131.14 (2C), 134.08, 134.91, 150.64, 151.15 (arom-C), 144.41 (triazole $\left.\mathrm{C}_{3}\right), 150.37(\mathrm{~N}=\mathrm{CH}), 155.02$ (triazole $\left.\mathrm{C}_{5}\right), 162.86(\mathrm{C}=\mathrm{O})$. UV $\lambda_{\max }(\varepsilon): 259$ (13175), $210(15433) \mathrm{nm}$. Anal. Calcd. for $\mathrm{C}_{22} \mathrm{H}_{15} \mathrm{~N}_{5} \mathrm{O}_{5}$ (429.39): C, 61.54; H, 3.52; N, 16.31. Found: C, 61.70; H, 3.53; N, 16.21.

\section{3-Cyclopropyl-4-[3-(4-nitrobenzoxy)benzylidenamino]-4,5-dihydro-1H-1,2,4- triazol-5-one $\mathbf{( 4 g )}$}

Yield 3.85 g (98\%). M.p. $215^{\circ} \mathrm{C}$. IR (KBr): NH 3175; C=O 1737, 1707; C=N 1607, 1578; $\mathrm{NO}_{2} 1525$ and 1350; COO 1260; 1,4-disubstituted benzenoid ring 842; 1,3-disubstituted benzenoid ring 785 and $713 \mathrm{~cm}^{-1}$. ${ }^{1} \mathrm{H}$ NMR (DMSO- $\left.\mathrm{d}_{6}\right): \delta 0.87-0.95\left(\mathrm{~m}, 4 \mathrm{H}, \mathrm{CH}_{2} \mathrm{CH}_{2}\right), 2.06-$ 2.20 (m, 1H, CH), 7.47-7.82 (m, 4H, Ar-H), 8.37 (s, 4H, Ar-H), 9.75 (s, 1H, N=CH), 11.81 (s, $1 \mathrm{H}, \mathrm{NH}) .{ }^{13} \mathrm{C}$ NMR (DMSO-d 6 ): $\delta 5.32,6.57$ (aliph-C), 120.00, 123.86 (2C), 124.73, 126.18, 130.25, 131.24 (2C), 134.17, 135.21, 150.71, 151.16 (arom-C), 148.17 (triazole $\mathrm{C}_{3}$ ), 150.46 $(\mathrm{N}=\mathrm{CH}), 152.53$ (triazole $\left.\mathrm{C}_{5}\right), 163.00(\mathrm{C}=\mathrm{O}) . \mathrm{UV} \lambda_{\max }(\varepsilon): 259(2870), 209(13810) \mathrm{nm}$.

\section{General procedure for the synthesis of compounds $\mathbf{5}$}

The corresponding compound $4(0.01 \mathrm{~mol})$ was refluxed with acetic anhydride $(20 \mathrm{~mL})$ for 0.5 $\mathrm{h}$. After the addition of absolute ethanol $(100 \mathrm{~mL})$, the mixture was refluxed for $1 \mathrm{~h}$ more. Evaporation of the resulting solution at $40-45^{\circ} \mathrm{C}$ in vacuo and several recrystallizations of the residue from ethyl alcohol gave pure compounds $\mathbf{5}$ as colorless needles.

\section{1-Acetyl-3-methyl-4-[3-(4-nitrobenzoxy)benzylidenamino]-4,5-dihydro-1H-1,2,4- triazol-5-one (5a)}

Yield 4.00 g (98\%). M.p. $225^{\circ} \mathrm{C}$. IR (KBr): $\mathrm{C}=\mathrm{O}$ 1737, 1720; C=N 1619, 1598; $\mathrm{NO}_{2} 1528$ and 1349; COO 1262; 1,4-disubstituted benzenoid ring 836; 1,3-disubstituted benzenoid ring 765 and $714 \mathrm{~cm}^{-1} .{ }^{1} \mathrm{H}$ NMR (DMSO-d $\left.{ }_{6}\right): \delta 2.33\left(\mathrm{~s}, 3 \mathrm{H}, \mathrm{CH}_{3}\right), 2.46\left(\mathrm{~s}, 3 \mathrm{H}, \mathrm{COCH}_{3}\right), 7.54-$ $7.84(\mathrm{~m}, 4 \mathrm{H}, \mathrm{Ar}-\mathrm{H}), 8.37$ (s, 4H, Ar-H), $9.61(\mathrm{~s}, 1 \mathrm{H}, \mathrm{N}=\mathrm{CH}) .{ }^{13} \mathrm{C}$ NMR (DMSO-d 6 ): $\delta 11.12$ $\left(\mathrm{CH}_{3}\right), 23.37\left(\mathrm{COCH}_{3}\right), 120.32,123.90$ (2C), 125.27, 126.51, 130.40, 131.28 (2C), 134.19, 134.66, 146.64, 150.74 (arom-C), $147.72\left(\right.$ triazole $\left.\mathrm{C}_{3}\right), 150.50(\mathrm{~N}=\mathrm{CH}), 154.22\left(\right.$ triazole $\left.\mathrm{C}_{5}\right)$, 163.03, 165.95 (2C=O). UV $\lambda_{\max }(\varepsilon): 255$ (29204), 220 (16347) nm.

\section{1-Acetyl-3-benzyl-4-[3-(4-nitrobenzoxy)benzylidenamino]-4,5-dihydro-1H-1,2,4- triazol-5-one (5c)}

Yield 4.00 g (83\%). M.p. $191{ }^{\circ} \mathrm{C}$. IR (KBr): $\mathrm{C}=\mathrm{O} 1732 ; \mathrm{C}=\mathrm{N} 1605,1585 ; \mathrm{NO}_{2} 1524$ and 1349; COO 1257; 1,4-disubstituted benzenoid ring 840; 1,3-disubstituted benzenoid ring 806 and $709 \mathrm{~cm}^{-1}$; monosubstituted benzenoid ring 763 and $706 \mathrm{~cm}^{-1} .{ }^{1} \mathrm{H}$ NMR (DMSO-d $\left.\mathrm{d}_{6}\right): \delta 2.47$ (s, $3 \mathrm{H}, \mathrm{COCH}_{3}$ ), 4.12 (s, 2H, $\mathrm{CH}_{2}$ ), 7.19-7.37 (m, 5H, Ar-H), 7.52-7.75 (m, 4H, Ar-H), 8.33-8.43 $(\mathrm{m}, 4 \mathrm{H}, \mathrm{Ar}-\mathrm{H}), 9.58(\mathrm{~s}, 1 \mathrm{H}, \mathrm{N}=\mathrm{CH}) .{ }^{13} \mathrm{C}$ NMR (DMSO-d $)$ : $\delta 23,44\left(\mathrm{COCH}_{3}\right), 30.94\left(\mathrm{CH}_{2}\right)$, $120.41,123.94$ (2C), 125.14, 126.38, 126.87, 128.38 (2C), 128.96 (2C), 130.35, 131.25 (2C), 134.14, 134.53, 134.66, 147.87, 150.68 (arom-C), 148.21 (triazole $\left.\mathrm{C}_{3}\right), 150.50(\mathrm{~N}=\mathrm{CH}), 153.66$ (triazole $\mathrm{C}_{5}$ ), 162.98, 165.89 (2C=O). UV $\lambda_{\max }(\varepsilon)$ : 256 (24585), 215 (24195) nm. Anal. Calcd. for $\mathrm{C}_{25} \mathrm{H}_{19} \mathrm{~N}_{5} \mathrm{O}_{6}$ (485.46): C, 61.85; H, 3.94; N, 14.43. Found: C, 61.81; H, 3.91; N, 14.49. 
1-Acetyl-3-p-Chlorobenzyl-4-[3-(4-nitrobenzoxy)benzylidenamino]-4,5-dihydro1H-1,2,4-triazol-5-one (5e)

Yield 4.57 g (88\%). M.p. $199^{\circ} \mathrm{C}$. IR (KBr): C=O 1781, 1766, 1735; C=N 1606, 1577; $\mathrm{NO}_{2}$ 1525 and 1368; COO 1258; 1,4-disubstituted benzenoid ring 841, 804; 1,3-disubstituted benzenoid ring 785 and $714 \mathrm{~cm}^{-1} .{ }^{1} \mathrm{H}$ NMR $\left(\mathrm{DMSO}-\mathrm{d}_{6}\right): \delta 2.48\left(\mathrm{~s}, 3 \mathrm{H}, \mathrm{COCH}_{3}\right), 4.14(\mathrm{~s}, 2 \mathrm{H}$, $\mathrm{CH}_{2}$ ), 7.35 (s, 4H, Ar-H), 7.53-7.77 (m, 4H, Ar-H), 8.40 (s, 4H, Ar-H), 9.59 (s, 1H, N=CH). ${ }^{13} \mathrm{C}$ NMR (DMSO-d $\left.)_{6}\right): \delta 23.44\left(\mathrm{COCH}_{3}\right), 30.27\left(\mathrm{CH}_{2}\right), 120.34,123.95(2 \mathrm{C}), 125.20$, $126.53,128.28(2 \mathrm{C}), 130.39,130.91(2 \mathrm{C}), 131.29(2 \mathrm{C}), 131.55,133.55,134.16,134.64$, 147.92, 150.70 (arom-C), 147.92 (triazole $\mathrm{C}_{3}$ ), $150.53(\mathrm{~N}=\mathrm{CH}), 153.70$ (triazole $\mathrm{C}_{5}$ ), 163.01, $165.85(2 \mathrm{C}=\mathrm{O})$. UV $\lambda_{\max }(\varepsilon): 257$ (6707), 207 (9133) nm.

\section{1-Acetyl-3-phenyl-4-[3-(4-nitrobenzoxy)benzylidenamino]-4,5-dihydro-1H-1,2,4- triazol-5-one (5f)}

Yield 4.06 g (86\%). M.p. $209{ }^{\circ} \mathrm{C}$. IR (KBr): $\mathrm{C}=\mathrm{O}$ 1740; $\mathrm{C}=\mathrm{N} 1607,1585 ; \mathrm{NO}_{2} 1527$ and 1349; COO 1256; 1,4-disubstituted benzenoid ring 843; 1,3-disubstituted benzenoid ring 788 and $710 \mathrm{~cm}^{-1}$; monosubstituted benzenoid ring 770 and $689 \mathrm{~cm}^{-1} .{ }^{1} \mathrm{H}$ NMR (DMSO-d 6 ): $\delta 2.54\left(\mathrm{~s}, 3 \mathrm{H}, \mathrm{COCH}_{3}\right), 7.49-7.60(\mathrm{~m}, 5 \mathrm{H}, \mathrm{Ar}-\mathrm{H}), 7.73-7.91$ (m, 4H, Ar-H), 8.28-8.39 (m, $4 \mathrm{H}, \mathrm{Ar}-\mathrm{H}), 9.52(\mathrm{~s}, 1 \mathrm{H}, \mathrm{N}=\mathrm{CH}) .{ }^{13} \mathrm{C}$ NMR $\left(\mathrm{DMSO}_{-} \mathrm{d}_{6}\right): \delta 23.47\left(\mathrm{COCH}_{3}\right), 120.95,123.86$ (2C), 125.04, 125.41, 126.06, 128.57 (4C), 130.45, 131.24 (3C), 134.10, 134.37, 145.88, 150.69 (arom-C), 147.98 (triazole $\left.\mathrm{C}_{3}\right), 150.44(\mathrm{~N}=\mathrm{CH}), 157.25$ (triazole $\left.\mathrm{C}_{5}\right), 162.93,166.14$ $(2 \mathrm{C}=\mathrm{O}) . \mathrm{UV} \lambda_{\max }(\varepsilon): 259$ (12677), 205 (12200) nm.

General procedure for the synthesis of compounds 7

The corresponding compound $2(0.01 \mathrm{~mol})$ was dissolved in $2 \mathrm{~N} \mathrm{NaOH}(10 \mathrm{~mL})$ and treated with dimethyl sulphate $(2.08 \mathrm{~mL})$. After stirring of the mixture at room temperature for $1 \mathrm{~h}$, the solid formed was filtered, washed with cold water $(15 \mathrm{~mL})$ and dried in vacuo. Several recrystallizations of the residue from an appropriate solvent gave pure compounds $\mathbf{6}$ as colourless needles. Then compound $6(0.01 \mathrm{~mol})$ was dissolved in acetic acid $(15 \mathrm{~mL})$ and treated with 3-(4-nitrobenzoxy) benzaldehyde $3(0.01 \mathrm{~mol})$. The mixture was refluxed for $1.5 \mathrm{~h}$ and then evaporated at $50-55{ }^{\circ} \mathrm{C}$ in vacuo. Several recrystallizations of the residue from ethyl alcohol gave pure compounds $\mathbf{7}$ as colorless crystals.

1-Methyl-3-benzyl-4-[3-(4-nitrobenzoxy)benzylidenamino]-4,5-dihydro-1H-1,2,4triazol-5-one $(7 \mathrm{c})$

Yield 3.10 g (68\%). M.p. $163{ }^{\circ} \mathrm{C}$. IR (KBr): $\mathrm{C}=\mathrm{O}$ 1742, 1709; C=N 1602, 1570; $\mathrm{NO}_{2} 1523$ and 1347; COO 1259; 1,4-disubstituted benzenoid ring 839; 1,3-disubstituted benzenoid ring 784 and $711 \mathrm{~cm}^{-1}$; monosubstituted benzenoid ring 762 and $680 \mathrm{~cm}^{-1} .{ }^{1} \mathrm{H}$ NMR (DMSO$\left.\mathrm{d}_{6}\right): \delta 3.32\left(\mathrm{~s}, 3 \mathrm{H}, \mathrm{NCH}_{3}\right), 4.04\left(\mathrm{~s}, 2 \mathrm{H}, \mathrm{CH}_{2}\right), 7.28(\mathrm{~m}, 5 \mathrm{H}, \mathrm{Ar}-\mathrm{H}), 7.49-7.73(\mathrm{~m}, 4 \mathrm{H}, \mathrm{Ar}-\mathrm{H})$, $8.37(\mathrm{~m}, 4 \mathrm{H}, \mathrm{Ar}-\mathrm{H}), 9.67(\mathrm{~s}, 1 \mathrm{H}, \mathrm{N}=\mathrm{CH}) .{ }^{13} \mathrm{C}$ NMR $\left(\mathrm{DMSO}-\mathrm{d}_{6}\right): \delta 30.70\left(\mathrm{CH}_{2}\right), 31.80$ $\left(\mathrm{NCH}_{3}\right), 120.27,123.92$ (2C), 124.78, 126.05, 126.63, 128.32 (2C), 128.80 (2C), 130.25, 131.25 (2C), 134.17, 134.96, 135.38, 144.64, 150.68 (arom-C), 149.25 (triazole $\mathrm{C}_{3}$ ), 150.50 $(\mathrm{N}=\mathrm{CH}), 152.09$ (triazole $\mathrm{C}_{5}$ ), $163.05(\mathrm{C}=\mathrm{O}) . \mathrm{UV} \lambda_{\max }(\varepsilon)$ : 259 (26187), $219(19760) \mathrm{nm}$.

1-Methyl-3-phenyl-4-[3-(4-nitrobenzoxy)benzylidenamino]-4,5-dihydro-1H-1,2,4triazol-5-one (5f)

Yield 3.00 g (68\%). M.p. $192{ }^{\circ} \mathrm{C}$. IR (KBr): $\mathrm{C}=\mathrm{O}$ 1733, 1707; C=N 1607, 1576; $\mathrm{NO}_{2} 1525$ and 1350; COO 1263; 1,4-disubstituted benzenoid ring 841; 1,3-disubstituted benzenoid ring 
780 and $713 \mathrm{~cm}^{-1}$; monosubstituted benzenoid ring 773 and $686 \mathrm{~cm}^{-1} .{ }^{1} \mathrm{H}$ NMR (DMSO-d 6 ): $\delta 3.43\left(\mathrm{~s}, 3 \mathrm{H}, \mathrm{NCH}_{3}\right), 7.47-7.63(\mathrm{~m}, 5 \mathrm{H}, \mathrm{Ar}-\mathrm{H}), 7.71-7.84(\mathrm{~m}, 4 \mathrm{H}, \mathrm{Ar}-\mathrm{H}), 8.28-8.39(\mathrm{~m}, 4 \mathrm{H}$, Ar-H), $9.64(\mathrm{~s}, 1 \mathrm{H}, \mathrm{N}=\mathrm{CH}) .{ }^{13} \mathrm{C}$ NMR $\left(\mathrm{DMSO}_{6}\right): \delta 32.20\left(\mathrm{NCH}_{3}\right), 120.92,123.84(2 \mathrm{C})$, $125.10,125.81,127.85$ (2C), 128.49 (2C), 130.15, 130.35, 130.70, 131.21 (2C), 134.20, 134.72, 147.20, 150.40 (arom-C), 149.50 (triazole $\left.\mathrm{C}_{3}\right), 150.67(\mathrm{~N}=\mathrm{CH}), 155.80$ (triazole $\mathrm{C}_{5}$ ), $163.05(\mathrm{C}=\mathrm{O})$. UV $\lambda_{\max }(\varepsilon): 261$ (28133), 217 (20933) nm. Anal. Calcd. for $\mathrm{C}_{23} \mathrm{H}_{17} \mathrm{~N}_{5} \mathrm{O}_{5}$ (443,42): C, 62.30; H, 3.86; N, 15.79. Found: C, 62.31; H, 3.86; N, 15.78.

\section{Reducing power}

The reducing power of the synthesized compounds (except $\mathbf{5 f}$ ) was determined according to the method of Oyaizu ${ }^{20}$. Different concentrations of the samples $(50-250 \mu \mathrm{g} / \mathrm{mL})$ in DMSO $(1$ $\mathrm{mL})$ were mixed with phosphate buffer $(2.5 \mathrm{~mL}, 0.2 \mathrm{M}, \mathrm{pH}=6.6)$ and potassium ferricyanide $(2.5 \mathrm{~mL}, 1 \%)$. The mixture was incubated at $50{ }^{\circ} \mathrm{C}$ for $20 \mathrm{~min}$. after which a portion $(2.5 \mathrm{~mL})$ of trichloroacetic acid (10\%) was added to the mixture, which was then centrifuged for $10 \mathrm{~min}$ at $1000 \mathrm{x}$ g. The upper layer of solution $(2.5 \mathrm{~mL})$ was mixed with distilled water $(2.5 \mathrm{~mL})$ and $\mathrm{FeCl}_{3}(0.5 \mathrm{~mL}, 0.1 \%)$ and then the absorbance at $700 \mathrm{~nm}$ was measured in a spectrophometer. Higher absorbance of the reaction mixture indicated greater reducing power.

\section{Free radical scavenging activity}

Free radical scavenging activity of compounds was measured by DPPH; using the method of Blois $^{21}$. Briefly, $0.1 \mathrm{mM}$ solution of DPPH in ethanol was prepared, and this solution $(1 \mathrm{~mL})$ was added to sample solutions in DMSO $(3 \mathrm{~mL})$ at different concentrations $(50-250 \mu \mathrm{g} / \mathrm{mL})$. The mixture was shaken vigorously and allowed to stand at room temperature for $30 \mathrm{~min}$. Then the absorbance was measured at $517 \mathrm{~nm}$ in a spectrophometer. Lower absorbance of the reaction mixture indicated higher free radical scavenging activity. The DPPH concentration $(\mathrm{mM})$ in the reaction medium was calculated from the following calibration curve and determined by linear regression ( $\mathrm{R}$ : 0.997): Absorbance $=0.0003 \times \mathrm{DPPH}-0.0174$. The capability to scavenge the DPPH radical was calculated using the following equation:

$$
\text { DPPH scavenging effect }(\%)=\left(\mathrm{A}_{0}-\mathrm{A}_{1} / \mathrm{A}_{0}\right) \times 100
$$

Where, $A_{0}$ is the absorbance of the control reaction and $A_{1}$ is the absorbance in the presence of the samples or standards.

\section{Metal chelating activity}

The chelation of ferrous ions by the synthesized compounds and standards were estimated by the method of Dinis et $a l^{22}$. Briefly, the synthesized compounds $(50-250 \mu \mathrm{g} / \mathrm{mL})$ were added to a $2 \mathrm{mM}$ solution of $\mathrm{FeCl}_{2}(0.05 \mathrm{~mL})$. The reaction was initiated by the addition of 5 $\mathrm{mM}$ ferrozine $(0.2 \mathrm{~mL})$ and the mixture was shaken vigorously and left standing at room temperature for $10 \mathrm{~min}$. After the mixture had reached equilibrium, the absorbance of the solution was then measured at $562 \mathrm{~nm}$ in a spectrophotometer. All test and analyses were run in triplicate and averaged. The percentage of inhibition of ferrozine-Fe ${ }^{2+}$ complex formation was given by the formula: \% Inhibition $=\left(A_{0}-A_{1} / A_{0}\right) \times 100$, where $A_{0}$ is the absorbance of the control, and $A_{1}$ is the absorbance in the presence of the samples or standards. The control did not contain compound or standard.

\section{Potentiometric titrations}

A Jenway 3040-model ion analyzer and an Ingold $\mathrm{pH}$ electrode were used for potentiometric titrations. For each compound that would be titrated, the $0.001 \mathrm{M}$ solution was separately prepared in each non-aqueous solvent. The $0.05 \mathrm{M}$ solution of TBAH in isopropyl alcohol, which is widely used in the titration of acids, was used as titrant. The $\mathrm{mV}$ values that were 
obtained in $\mathrm{pH}$-meter were recorded. Finally, the HNP values were determined by drawing the $\mathrm{mL}$ (TBAH)-mV graphic.

\section{Statistical analysis}

Statistical significance of differences between the mean activities of the subgroups of compounds was determined by utilizing ANOVA for variables with normal distributions and the Kruskal Wallis test for variables not normally distributed. All results are presented as means \pm standard deviation (SD). Differences were considered significant at $\mathrm{p}<0.05$. SPSS computer software was used for all statistical calculations.

\section{Results and Discussion}

The 3-alkyl(aryl)-4-[3-(4-nitrobenzoxy)-benzylidenamino]-4,5-dihydro-1 H-1,2,4-triazol-5one (4a-g) were prepared. The starting compounds 3-alkyl(aryl)-4-amino-4,5-dihydro- $1 \mathrm{H}$ 1,2,4-triazol-5-ones (2a-g) were prepared from the reactions of the corresponding ester ethoxycarbonylhydrazones (1a-g) with an aqueous solution of hydrazine hydrate as described in the literature ${ }^{14,19,23}$. Compounds 4 were obtained from the reactions of compounds 2 with 3-(4-nitrobenzoxy)benzaldehyde (3) which were synthesized by the reactions of 3-hydroxybenzaldehyde with 4-nitrobenzoyl chloride by using triethylamine. Then the reactions of compounds $\mathbf{4 a}, \mathbf{4 c}, \mathbf{4 e}$, and $\mathbf{4 f}$ with acetic anhydride were investigated and compounds $\mathbf{5 a}, \mathbf{5 c}, \mathbf{5 e}$, and $\mathbf{5 f}$ were prepared. Moreover, the reactions of compounds $\mathbf{2 c}$ and $2 \mathbf{f}$ with $\mathrm{NaOH} /$ dimethyl sulphate gave compounds $\mathbf{6 c}$, 6f. Finally, compounds 7c, 7f were synthesized by the reactions of compounds $\mathbf{6 c}, \mathbf{6} \mathbf{f}$ and compound $\mathbf{3}$ (Scheme 1).

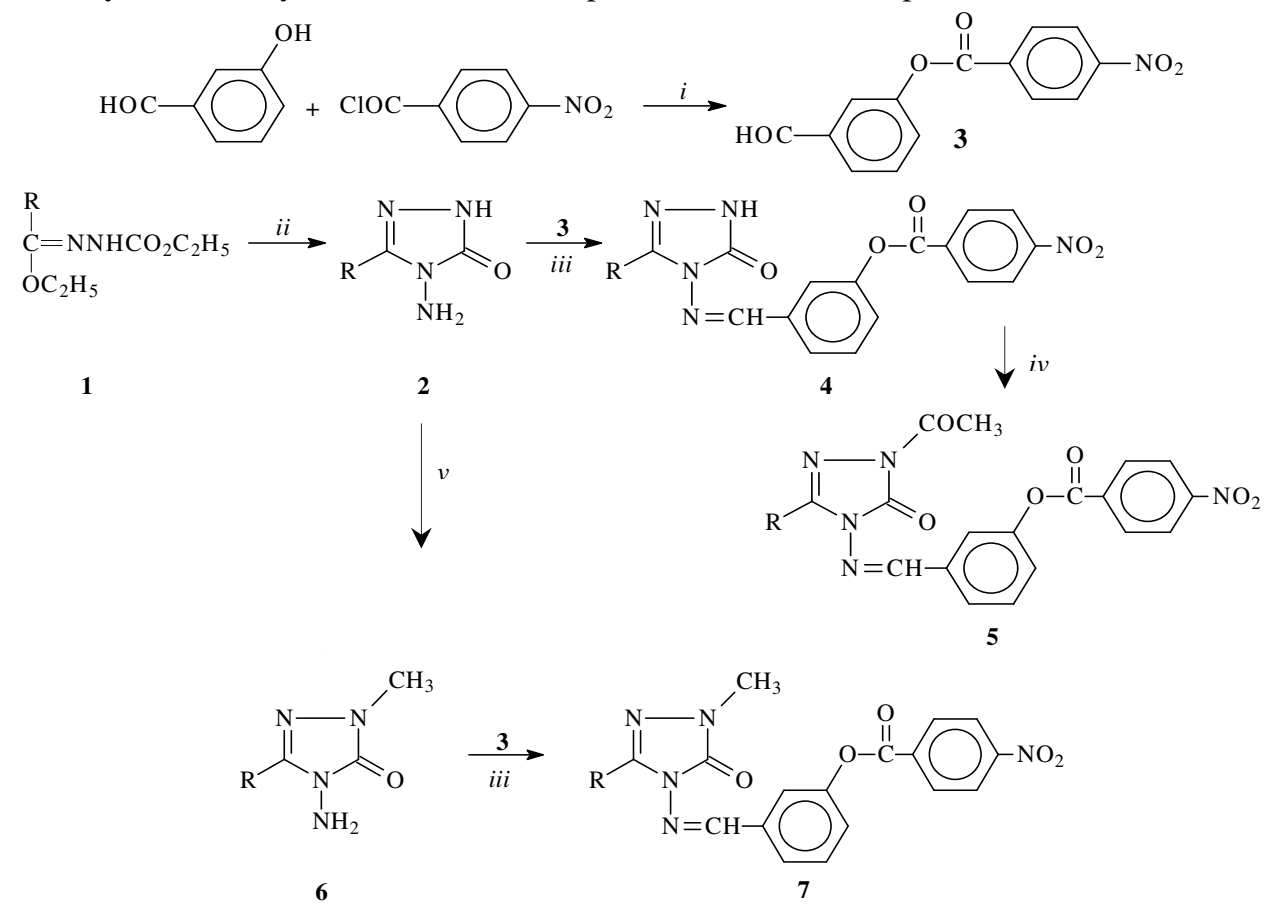

Scheme 1. Synthesis route of compounds $2-7$

i) $\mathrm{Et}_{3} \mathrm{~N}$, AcOEt, $0-5{ }^{\circ} \mathrm{C}$; ii) $\mathrm{N}_{2} \mathrm{H}_{4}, \mathrm{H}_{2} \mathrm{O}$, reflux, $6 \mathrm{~h}$; iii) $\mathrm{AcOH}$, reflux, $1 \mathrm{~h}$; iv) $\mathrm{Ac}_{2} \mathrm{O}$, reflux, $1 \mathrm{~h}$; v) $2 \mathrm{~N}$ $\mathrm{NaOH},\left(\mathrm{CH}_{3}\right)_{2} \mathrm{SO}_{4}$, a) $\mathrm{R}=\mathrm{CH}_{3}$, b) $\mathrm{R}=\mathrm{CH}_{2} \mathrm{CH}_{3}$, c) $\mathrm{R}=\mathrm{CH}_{2} \mathrm{C}_{6} \mathrm{H}_{5}$, d) $\mathrm{R}=\mathrm{CH}_{2} \mathrm{C}_{6} \mathrm{H}_{4} \cdot \mathrm{CH}_{3}$ (p-), e) $\mathrm{R}=$ $\left.\left.\mathrm{CH}_{2} \mathrm{C}_{6} \mathrm{H}_{4} \cdot \mathrm{Cl}(p-), \mathrm{f}\right) \mathrm{R}=\mathrm{C}_{6} \mathrm{H}_{5}, \mathrm{~g}\right) \mathrm{R}=$ cyclopropyl. 
The structures of seven new 3-alkyl(aryl)-4-[3-(4-nitrobenzoxy)-benzylidenamino]-4,5dihydro-1H-1,2,4-triazol-5-one 4a-g, four new 1-acetyl-3-alkyl(aryl)-4-[3-(4-nitrobenzoxy)benzylidenamino]-4,5-dihydro- $1 H-1,2,4$-triazol-5-one 5a, 5c, 5e, 5f and two new 1-methyl-3-alkyl(aryl)-4-[3-(4-nitrobenzoxy)benzylidenamino]-4,5-dihydro-1 $\mathrm{H}$-1,2,4triazol-5-one 7c, 7f were identified using IR, ${ }^{1} \mathrm{H}$ NMR, ${ }^{13} \mathrm{C} N \mathrm{NMR}$, UV and elemental analyses data.

\section{Antioxidant activity}

The antioxidant activities of 13 new compounds $4 \mathbf{4 a - g}, \mathbf{5 a}, \mathbf{5 c}, \mathbf{5 e}, \mathbf{5 f}, \mathbf{7 c}, \mathbf{7 f}$ were determined. The structure-activity relationship studies of compounds were done by statistical analysis. Several methods are used to determine antioxidant activities. The methods used in the study are given below:

\section{Total reductive capability using the potassium ferricyanide reduction method}

The reductive capabilities of compounds are assessed by the extent of conversion of the $\mathrm{Fe}^{3+}$ / ferricyanide complex to the $\mathrm{Fe}^{2+}$ / ferrous form using the method of Oyaizu ${ }^{20}$. The reducing powers of the compounds were observed at different concentrations, and results were compared with BHA, BHT and $\alpha$-tocopherol. The reducing capacity of a compound may serve as a significant indicator of its potential antioxidant activity ${ }^{24}$. The antioxidant activity of putative antioxidant has been attributed to various mechanisms, among which are prevention chain initiation, binding of transition metal ion catalyst, decomposition of peroxides, prevention of continued hydrogen abstraction, reductive capacity and radical scavenging ${ }^{25}$. In this study, all of the amounts of the compounds showed lower absorbance then blank. Hence, no activities were observed to reduce metal ions complexes to their lower oxidation state or to take part in any electron transfer reaction. In other words, compounds did not show the reductive activities.

\section{$D P P H^{\circ}$ radical scavenging activity}

The model of scavenging the stable DPPH radical model is a widely used method to evaluate antioxidant activities in a relatively short time compared with other methods. The effect of antioxidants on DPPH radical scavenging was thought to be due to their hydrogen donating ability ${ }^{26}$. DPPH is a stable free radical and accepts an electron or hydrogen radical to become a stable diamagnetic molecule ${ }^{22}$. The reduction capability of DPPH radicals was determined by decrease in its absorbance at $517 \mathrm{~nm}$ induced by antioxidants. The absorption maximum of a stable DPPH radical in ethanol was at $517 \mathrm{~nm}$. The decrease in absorbance of DPPH radical caused by antioxidants, because of reaction between antioxidant molecules and radical, progresses, which result in the scavenging of the radical by hydrogen donation. It is visually noticeable as a discoloration from purple to yellow. Hence, DPPH' is usually used as a substrate to evaluate antioxidative activity of antioxidants ${ }^{27}$. In the study, antiradical activities of compounds and standard antioxidants such as BHA and $\alpha$ tocopherol were determined by using DPPH method. Scavenging effect values of compounds 4, and 5, 7, BHA and $\alpha$-tocopherol at different concentrations are given Figures 1, 2 respectively. All the compounds tested with this method showed lower absorbance than absorbance of the control reaction and higher absorbance than that of the standard antioxidant reactions. The data obtained in the study indicate that the newly synthesized compounds showed mild activities as a radical scavenger, indicating that it has moderate activities as hydrogen donors. 


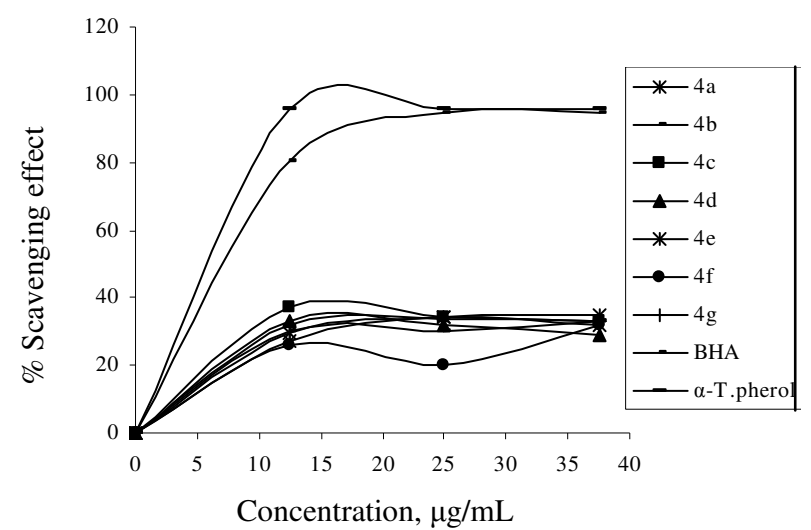

Figure 1. Scavenging effect of compounds 4a-g, BHA and $\alpha$-tocopherol at different concentrations $(12.5-25-37.5 \mu \mathrm{g} / \mathrm{mL})$.

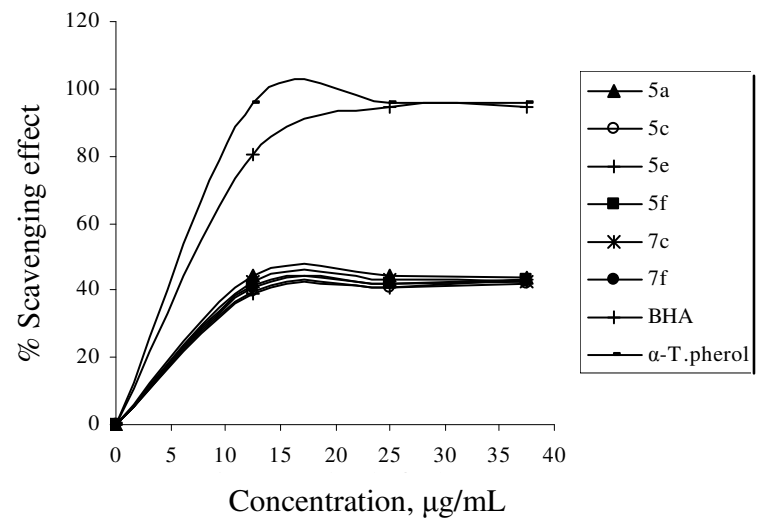

Figure 2. Scavenging effect of compounds 5a, 5c, 5e, 5f, 7c, 7f, BHA and $\alpha$-tocopherol at different concentrations (12.5-25-37.5 $\mu \mathrm{g} / \mathrm{mL})$.

\section{Ferrous ion chelating activity}

The chelating effect towards ferrous ions by the compounds and standards was determined according to the method of Dinis ${ }^{28}$. Ferrozine can quantitatively form complexes with $\mathrm{Fe}^{2+}$. In the presence of chelating agents, the complex formation is disrupted with the result that the red colour of the complex is decreased. Measurement of colour reduction therefore allows estimation of the chelating activity of the coexisting chelator ${ }^{29}$. Transition metals have pivotal role in the generation oxygen free radicals in living organism. The ferric iron $\left(\mathrm{Fe}^{3+}\right)$ is the relatively biologically inactive form of iron. However, it can be reduced to the active $\mathrm{Fe}^{2+}$, depending on condition, particularly $\mathrm{pH}^{30}$ and oxidized back through. Fenton type reactions with the production of hydroxyl radical or Haber-Weiss reactions with superoxide anions. The production of these radicals may lead to lipid peroxidation, protein modification and DNA damage. Chelating agents may not activate metal ions and potentially inhibit the metaldependent processes ${ }^{31}$. Also, the production of highly active ROS such as $\mathrm{O}_{2}{ }^{-{ }^{-}}, \mathrm{H}_{2} \mathrm{O}_{2}$ and $\mathrm{OH}^{-}$ is also catalyzed by free iron though Haber-Weiss reactions:

$$
\mathrm{O}_{2}^{\cdot}+\mathrm{H}_{2} \mathrm{O}_{2} \rightarrow \mathrm{O}_{2}+\mathrm{OH}^{-}+\mathrm{OH}^{\cdot}
$$

Among the transition metals, iron is known as the most important lipid oxidation prooxidant due to its high reactivity. The ferrous state of iron accelerates lipid oxidation by 
breaking down the hydrogen and lipid peroxides to reactive free radicals via the Fenton reactions:

$$
\mathrm{Fe}^{2+}+\mathrm{H}_{2} \mathrm{O}_{2} \rightarrow \mathrm{Fe}^{3+}+\mathrm{OH}^{-}+\mathrm{OH}^{\cdot}
$$

$\mathrm{Fe}^{3+}$ ion also produces radicals from peroxides, although the rate is tenfold less than that of $\mathrm{Fe}^{2+}$ ion, which is the most powerful pro-oxidant among the various types of metal ions ${ }^{32}$. Ferrous ion chelating activities of the compounds 4, and 5, 7, BHT and $\alpha$-tocopherol are shown in Figures 3 and 4, respectively. In this study, metal chelating capacity was significant since it reduced the concentrations of the catalyzing transition metal. It was reported that chelating agents that form $\sigma$-bonds with a metal are effective as secondary antioxidants because they reduce the redox potential thereby stabilizing the oxidized form of metal ion ${ }^{33}$. The data obtained from Figures 3 and 4 reveal that the compounds, especially $\mathbf{5 a}$ and 7c, demonstrate a marked capacity for iron binding, suggesting that their action as peroxidation protectors may be related to their iron binding capacity. On the other hand, free iron is known to have low solubility and a chelated iron complex has greater solubility in solution, which can be contributed solely by the ligand. Furthermore, the compound-iron complex may also be active, since it can participate in iron-catalyzed reactions.

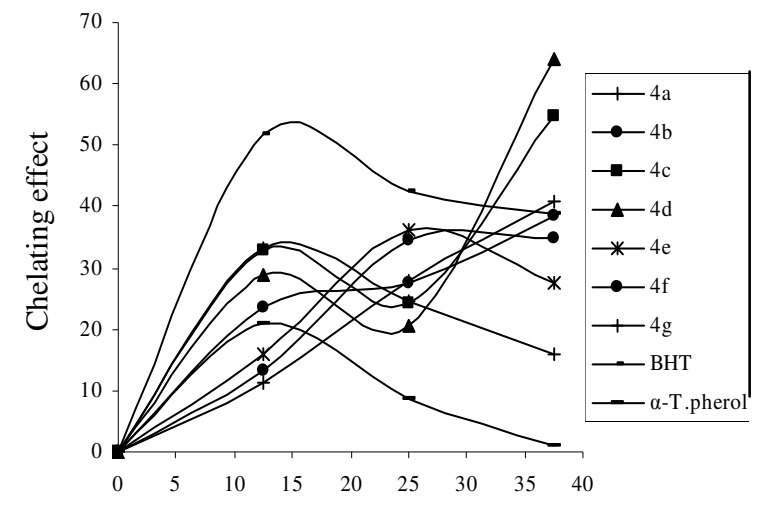

Concentration, $\mu \mathrm{g} / \mathrm{mL}$

Figure 3. Metal chelating effect of different amount of the compounds 4a-g, BHT and $\alpha$ tocopherol on ferrous ions.

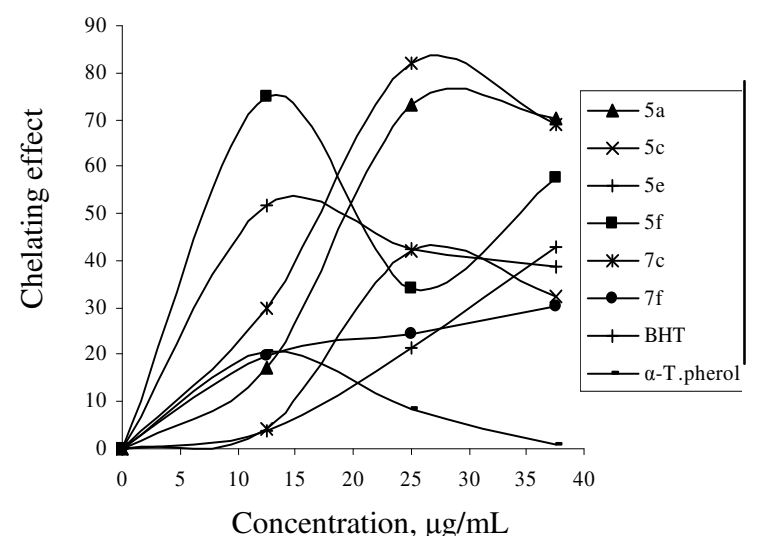

Figure 4. Metal chelating effect of different amount of the compounds $5 \mathbf{5 a}, \mathbf{5 c}, \mathbf{5 e}, \mathbf{5 f}, \mathbf{7 c}, \mathbf{7 f}$, BHT and $\alpha$-tocopherol on ferrous ions. 
The structure-activity relationship studies of compounds revealed that, when compared with compounds 4, $\mathrm{N}$-acetyl substitution of 4,5-dihydro-1 $\mathrm{H}$-1,2,4-triazol-5-one ring in compounds 5 decreased the reducing activity but increased the scavenging activity significantly. On the other hand, compounds 7 that have $N$-methyl substituted showed a significant increase in their reducing power when compared with $N$-acetyl substituted compounds 5, and also significant increase in the scavenging activity of them when compared with unsubstituted compounds $\mathbf{4}$. These results are shown in Table 1. Hence, these modifications included acetylation and methylation of the compounds $\mathbf{4}$ may be affected their electron transfer ability and hydrogen donating ability.

Table 1. The comparison of reducing power, DPPH scavenging, and chelating activities of compounds $\mathbf{4}, \mathbf{5}$, and $\mathbf{7}$.

\begin{tabular}{cccc}
\hline Compounds & $4(\mathrm{n}=21)$ & $5(\mathrm{n}=12)$ & $7(\mathrm{n}=6)$ \\
\hline Reducing power, $\mu \mathrm{g} / \mathrm{mL}, \mathrm{A}_{700} \mathrm{~nm}$ & $0,051 \pm 0,028^{\mathrm{a}}$ & $0,027 \pm 0,019^{\mathrm{b}}$ & $0,037 \pm 0,015^{\mathrm{a}}$ \\
$\begin{array}{c}\text { DPPH scavenging activity, } \\
\mu \mathrm{g} / \mathrm{mL}, \mathrm{A}_{517} \mathrm{~nm}, \% \text { inhibition } \\
\text { Metal chelating effect, }\end{array}$ & $31,44 \pm 3,68^{\mathrm{a}}$ & $42,01 \pm 1,74^{\mathrm{b}}$ & $42,28 \pm 0,71^{\mathrm{b}}$ \\
& $30,03 \pm 12,82^{\mathrm{a}}$ & $39,50 \pm 25,41^{\mathrm{a}}$ & $42,51 \pm 26,24^{\mathrm{a}}$ \\
\hline $\mathrm{g} / \mathrm{mL}, \mathrm{A}_{517} \mathrm{~nm}, \%$ inhibition & &
\end{tabular}

Each value is expressed as mean \pm standard deviation of sum of the tree different concentration measurements. Means with different letters within a row are significantly different $(\mathrm{p}<0.05)$.

In conclusion, the data here reported could be of the possible interest because of the observed radical scavenging and metal chelating activities of the studied compounds could prevent redox cycling. Design and synthesis of novel small molecules which can specifically protective role in biological systems are in perspective in modern medicinal chemistry. These results may also provide some guidance for the development of novel triazole-based therapeutic target.

\section{Potentiometric titrations}

In order to determine the $\mathrm{p} K_{\mathrm{a}}$ values of the compounds 4a-g they were titrated potentiometrically with TBAH in four non-aqueous solvents: isopropyl alcohol, tert-butyl alcohol, acetone and DMF. The $\mathrm{mV}$ values read in each titration were plotted against $0.05 \mathrm{M}$ TBAH volumes $(\mathrm{mL})$ added, and potentiometric titration curves were obtained for all the cases. From the titration curves, the HNP values were measured, and the corresponding $\mathrm{pK}_{\mathrm{a}}$ values were calculated. The data obtained from the potentiometric titrations was interpreted, and the effect of the C-3 substituent in 4,5-dihydro- $1 \mathrm{H}$-1,2,4-triazol-5-one ring as well as solvent effects were studied ${ }^{10-13,17,18,34}$. Determination of $\mathrm{p} K_{\mathrm{a}}$ values of the active constituent of certain pharmaceutical preparations is important because the distribution, transport behavior, bonding to receptors, and contributions to the metabolic behavior of the active constituent molecules depend on the ionization constant ${ }^{35-37}$.

As an example, the potentiometric titration curves for $0.001 \mathrm{M}$ solutions of compounds 4a-g titrated with 0.05 M TBAH in DMF is shown in Figure 5.

When the dielectric permittivity of solvents is taken into consideration, the acidity order can be given as follows: DMF $(\varepsilon=36.7)>$ acetone $(\varepsilon=36)>$ isopropyl alcohol $(\varepsilon=19.4)>$ tert-butyl alcohol $(\varepsilon=12)$. As seen in Table 2, the acidity order for compounds $\mathbf{4 a}$ and $\mathbf{4 f}$ is: isopropyl alcohol $>$ DMF $>$ tert-butyl alcohol $>$ acetone and for compounds $\mathbf{4 b}, \mathbf{4 d}, \mathbf{4 e}$, and $\mathbf{4 g}$ it is: isopropyl alcohol $>$ DMF $>$ acetone $>$ tert-butyl alcohol, while the order for compound $\mathbf{4 c}$ is: isopropyl alcohol $>$ tert-butyl alcohol $>$ DMF $>$ acetone. In isopropyl 
alcohol, all these compounds show the strongest acidic properties. Compounds $\mathbf{4 a}, \mathbf{4 c}$, and $\mathbf{4 f}$ show the weakest acidic properties in acetone and for compounds $\mathbf{4 b}, \mathbf{4 d}, \mathbf{4 e}$, and $\mathbf{4 g}$ it is in tert-butyl alcohol. This situation may be attributed to the hydrogen bonding between the negative ions formed and the solvent molecules in the amphiprotic neutral solvents.

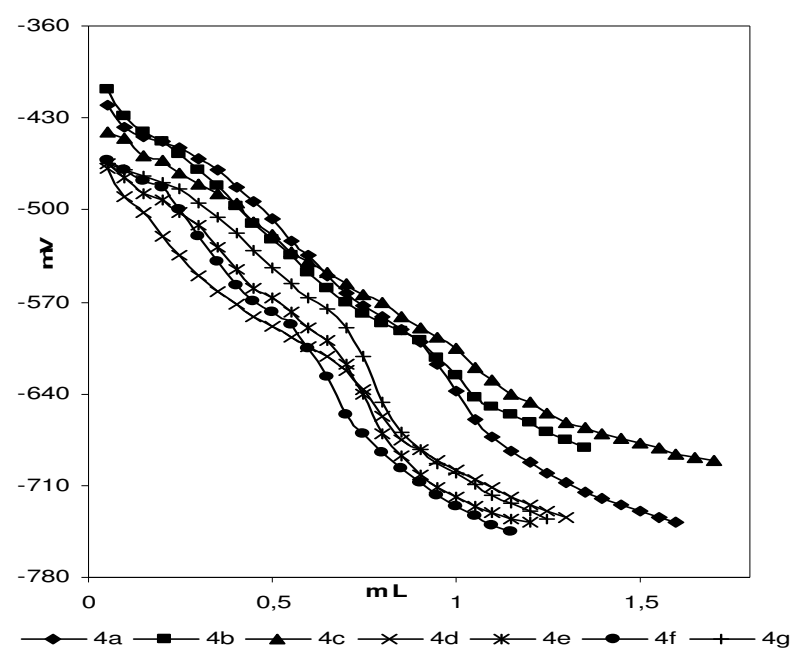

Figure 5. Potentiometric titration curves of $0.001 M$ solutions of compounds 4a-g titrated with $0.05 M$ TBAH in DMF at $25^{\circ} \mathrm{C}$.

Table 2. The HNP and the corresponding $\mathrm{p} K_{\mathrm{a}}$ values of compounds $\mathbf{4 a - g}$ in isopropyl alcohol, tert-butyl alcohol, DMF and acetone.

\begin{tabular}{|c|c|c|c|c|c|c|c|c|}
\hline \multirow{2}{*}{ Comp. } & \multicolumn{2}{|c|}{ Isopropyl alcohol } & \multicolumn{2}{|c|}{$\begin{array}{l}\text { tert-Butyl } \\
\text { alcohol }\end{array}$} & \multicolumn{2}{|c|}{ DMF } & \multicolumn{2}{|c|}{ Acetone } \\
\hline & $\begin{array}{l}\mathrm{HNP} \\
\mathrm{mV}\end{array}$ & $\mathrm{p} K_{\mathrm{a}}$ & $\begin{array}{l}\mathrm{HNP} \\
\mathrm{mV}\end{array}$ & $\mathrm{p} K_{\mathrm{a}}$ & $\begin{array}{l}\mathrm{HNP} \\
\mathrm{mV}\end{array}$ & $\mathrm{p} K_{\mathrm{a}}$ & $\begin{array}{c}\mathrm{HNP} \\
\mathrm{mV}\end{array}$ & $\mathrm{p} K_{\mathrm{a}}$ \\
\hline $4 a$ & -415 & 13,83 & -560 & 16,78 & -507 & 14,58 & -602 & 17,58 \\
\hline $4 b$ & -382 & 13,27 & -579 & 16,97 & -448 & 13,55 & -570 & 16,84 \\
\hline $4 c$ & -373 & 12,78 & -460 & 14,64 & -462 & 14,81 & -521 & 15,86 \\
\hline 4d & -380 & 12,84 & -550 & 16,16 & -567 & 15,59 & -539 & 16,00 \\
\hline $4 e$ & -361 & 12,47 & -562 & 16,41 & -536 & 15,08 & -533 & 16,24 \\
\hline $4 f$ & -353 & 12,52 & -501 & 15,39 & -529 & 14,88 & -517 & 15,68 \\
\hline $4 g$ & -402 & 13,26 & -561 & 16,28 & -506 & 14,35 & -505 & 15,37 \\
\hline
\end{tabular}

The degree to which a pure solvent ionizes was represented by its autoprotolysis constant, KHS.

For the above reaction the constant is defined by

$$
2 \mathrm{HS}=\mathrm{H}_{2} \mathrm{~S}^{+}+\mathrm{S}^{-}
$$

$$
\mathrm{K}_{\mathrm{HS}}=\left[\mathrm{H}_{2} \mathrm{~S}^{+}\right]\left[\mathrm{S}^{-}\right]
$$

Autoprotolysis is an acid-base reaction between identical solvent molecules is which some act as an acid and others as a base. Consequently, the extent of an autoprotolysis reaction depends both on the intrinsic acidity and the instrinsic basicity of the solvent. The importance of the autoprotolysis constant in titrations lies in its effect on the completeness of a titration reaction ${ }^{38}$. The exchange of the $\mathrm{pK}_{\mathrm{a}}$ values with autoprotolysis constant and 
dielectric constant are given in Figure 6. As it is well known, the acidity of a compound depends on some factors. The two most important factors are the solvent effect and molecular structure $\mathrm{e}^{10-13,17,18,34}$. Table 2 shows that the HNP values and corresponding $\mathrm{pKa}$ values obtained from the potentiometric titrations depend on the non-aqueous solvents used and the substituents at $\mathrm{C}-3$, in 4,5-dihydro- $1 \mathrm{H}$-1,2,4-triazol-5-one ring.

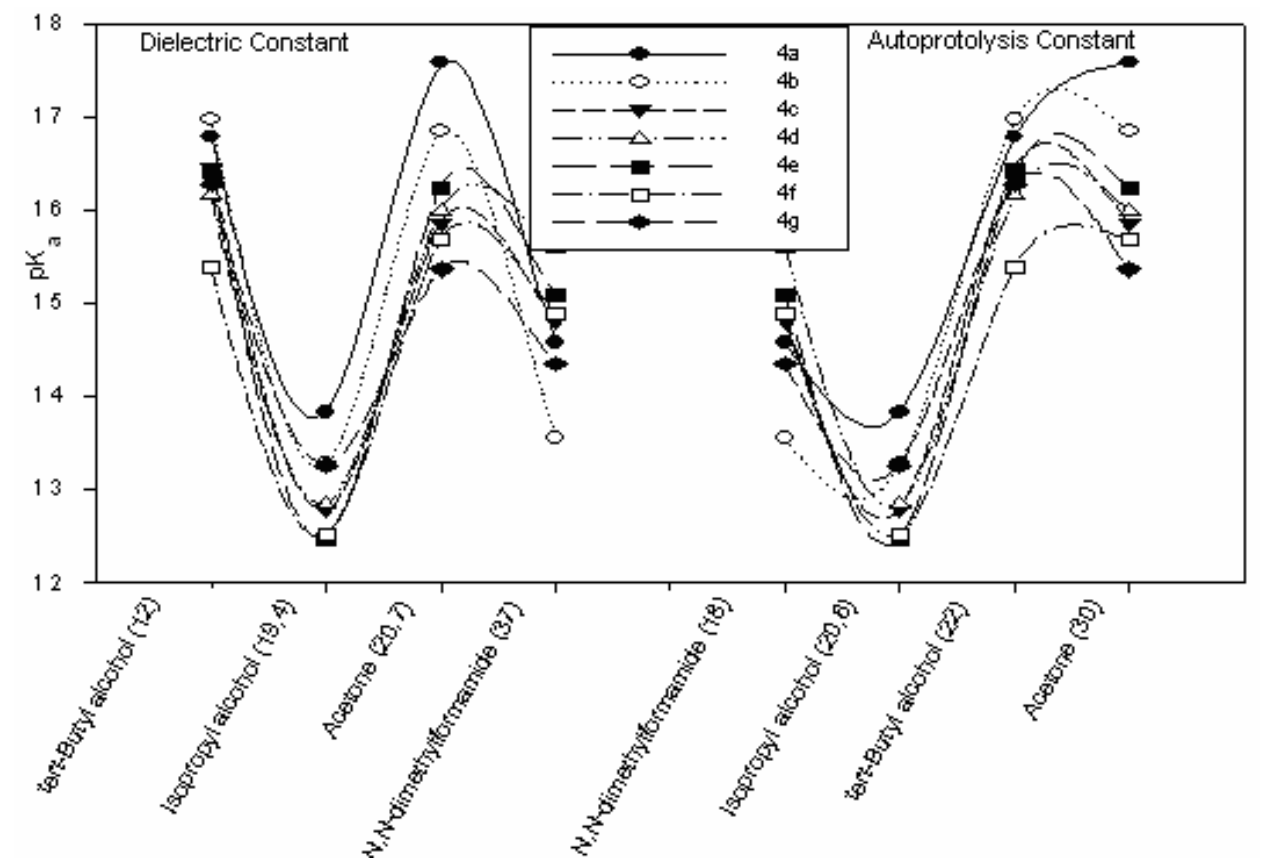

Figure 6. The variation of the $\mathrm{pK}_{\mathrm{a}}$ values for synthesized compounds 4a-g with dielectric and autoprotolysis constant

\section{Conclusion}

1,2,4-Triazoles have broad spectrum of biological activities. The synthesis and in vitro antioxidant evaluation of new 4,5-dihydro- $1 \mathrm{H}$-1,2,4-triazol-5-one derivatives are described. All of the compounds demonstrate a marked capacity for iron binding.

\section{Acknowledgements}

This work was supported by the Turkish Scientific and Technological Council (Project Number: TBAG 107T247). The authors thank Dr. Zafer Ocak (for determination of $\mathrm{pK}_{\mathrm{a}}$ values), Dr. Mustafa Calapoğlu and Dr. Mahfuz Elmastaş (for antioxidant activities).

\section{References}

1 Turan-Zitouni G, Kaplancikli Z A, Yildiz M T, Chevallet P and Kaya D, Eur J Med Chem., 2005, 40, 607.

2 Papakonstantinou-Garoufalias S, Pouli N, Marakos P and Chytyroglou-Ladas A, Il Farmaco, 2002, 57, 973.

3 Palaska E, Sahin G, Kelicen P, Durlu N T and Altınok G, Il Farmaco, 2002, 57, 101.

4 Ikizler A A, Uçar F, Yuksek H, Aytin A, Yasa I and Gezer T, Acta Pol Pharm: Drug Res., 1997, 54, 135. 
5 Yüksek H, Kolaylı S, Küçük M, Yüksek M O, Ocak U, Şahinbaş E, Sivrikaya E and Ocak M, Indian J Chem., 2006, 45B, 715.

6 Hashem A I, Youssef A S A, Kandeel K A and Abou-Elmalgd W S I, Eur J Med Chem., 2007, 42, 934.

7 Bekircan O, Kahveci B and Kucuk M, Turk J Chem., 2006, 30, 29.

8 Turan-Zitouni G, Kaplancikli Z A, Erol K and Kilic F S, Il Farmaco, 1999, 54, 218.

9 Chen J, Sun X Y, Chai K Y, Lee J S, Song M S and Quan Z S, Bioorg Med Chem., 2007, 15, 6775.

10 Bahçeci Ş, Yüksek H, Ocak Z, Azaklı I, Alkan M and Ozdemir M, Collect Czech Chem Commun., 2002, 67, 1215.

11 Yüksek H, Ocak Z, Özdemir M, Ocak M, Bekar M and Aksoy M, Indian J Heterocyl Chem., 2003, 13, 49.

12 Yüksek H, Bahçeci Ş, Ocak Z, Alkan M, Ermiş B, Mutlu T, Ocak M and Özdemir M, Indian J Heterocy Ch., 2004, 13, 369.

13 Yüksek H, Üçüncü O, Alkan M, Ocak Z, Bahçeci Ş and Özdemir M, Molecules, 2005, 10, 961.

14 Ikizler A A and Yüksek H, Org Prep Proced Int., 1993, 25, 99.

15 Hussain H H, Babic G, Durst T, Wright J, Flueraru M, Chichirau A and Chepelev L L, J Org Chem., 2003, 68, 7023.

16 McClements J and Decker E A, J Food Sci., 2000, 65, 1270.

17 Yüksek H, Ocak Z, Alkan M, Bahçeci Ş and Özdemir M, Molecules, 2004, 9, 232.

18 Yüksek H, Alkan M, Ocak Z, Bahçeci Ş, Ocak M and Özdemir M, Indian J Chem., 2004, 43B, 1527.

19 Ikizler A A and Un R, Chim Acta Turc. 1979, 7, 269; Chem Abstr 1991, 94, 15645d.

20 Oyaizu M, Japan J Nutri., 1986, 44, 307.

21 Blois M S, Nature, 1958, 26, 1199.

Soares J R, Dinis T C P, Cunha A P and Ameida L M, Free Rad Res., 1997, 26, 469.

Yüksek H, Demibaş A, Ikizler A, Johansson C B, Çelik C and Ikizler A A, Arzneim.Forsch Drug Res., 1997, 47, 405.

24 Meir S, Kanner J, Akiri B and Hadas S P, J Agri Food Chem., 1995, 43, 1813.

Yildirim A, Mavi A and Kara A A, J Agri Food Chem., 2001, 49, 4083.

Baumann J, Wurn G and Bruchlausen V, N-S Arch Pharmacol., 1979, 308, 27.

Duh P D, Tu Y Y and Yen G C, Lebn Wissen Technol., 1999, 32, 269.

Dinis T C P, Madeira V M C and Almeida L M, Arch Biochem Biophys., 1994, 315, 161.

Yamaguchi F, Ariga T, Yoshimira Y and Nakazawa H, J Agri Food Chem., 2000, 48, 180.

30 Strlic M, Radovic T, Kolar J and Pihlar B, J Agri Food Chem., 2002, 50, 6313.

Finefrock A E, Bush A I and Doraiswamy P M, J Am Geriatr Soc., 2003, 51, 1143.

Çaliş I, Hosny M, Khalifa T and Nishibe S, Phytochemistry., 1993, 33, 1453.

Bahçeci Ş, Yüksek H, Ocak Z, Köksal C and Ozdemir M, Acta Chim Slov., 2002, 49,783.

35 Frey P A, Kokesh F O and Westheim F H, J Am Chem Soc., 1971, 93, 7266.

36 Pütün A E, Bereket G and Keskin E, J Chem Eng Data, 1995, 40, 221.

37 Demirbaş A, Kula I, Erdoğan Y, Aslan A, Yaylı N and Karslığlu S, Energy Education Science and Technology., 1998, 1, 13.

38 Hargis L G, Analytical Chemistry Principles and Techniques; Prentice-Hall Inc., 1988. 


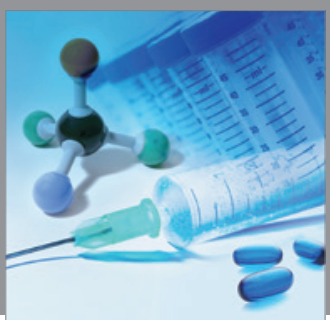

International Journal of

Medicinal Chemistry

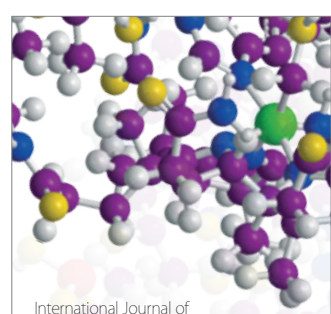

Carbohydrate Chemistry

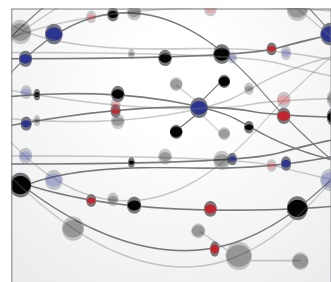

The Scientific World Journal
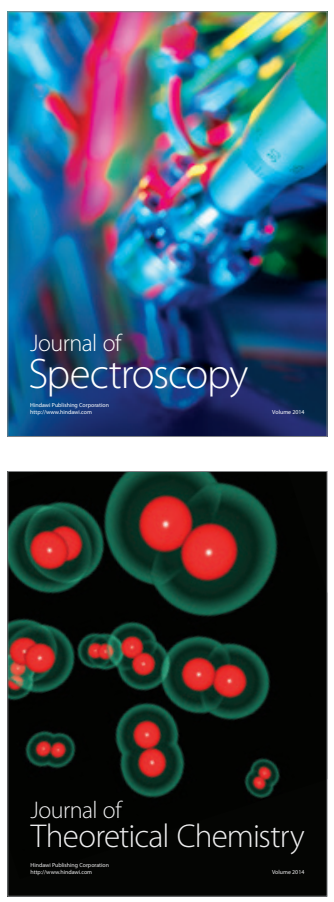
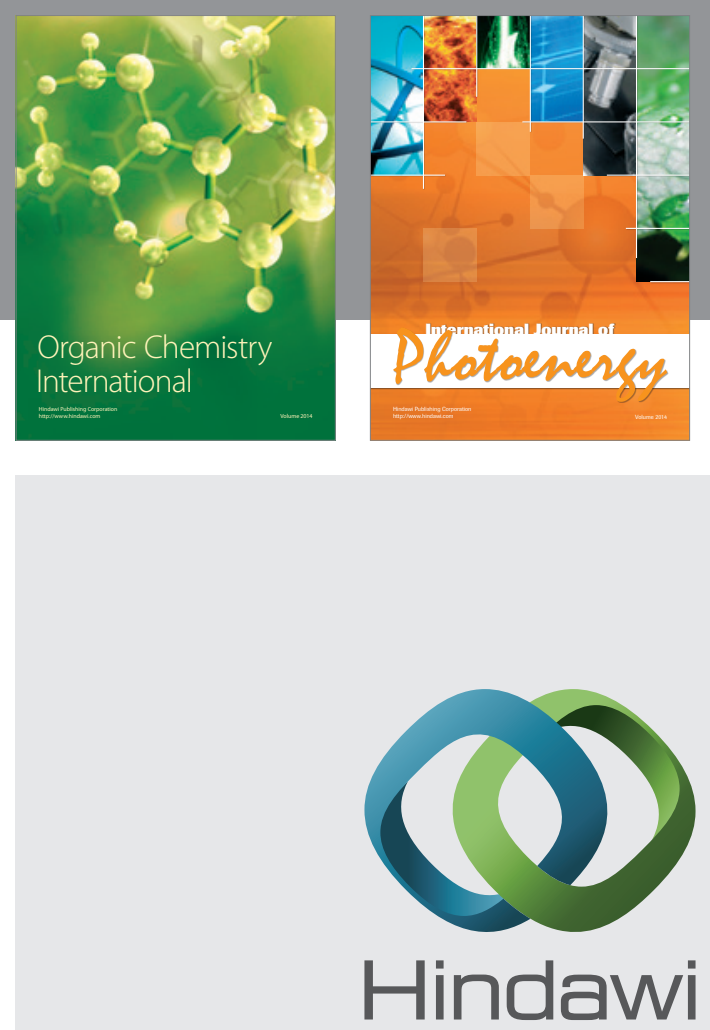

Submit your manuscripts at

http://www.hindawi.com
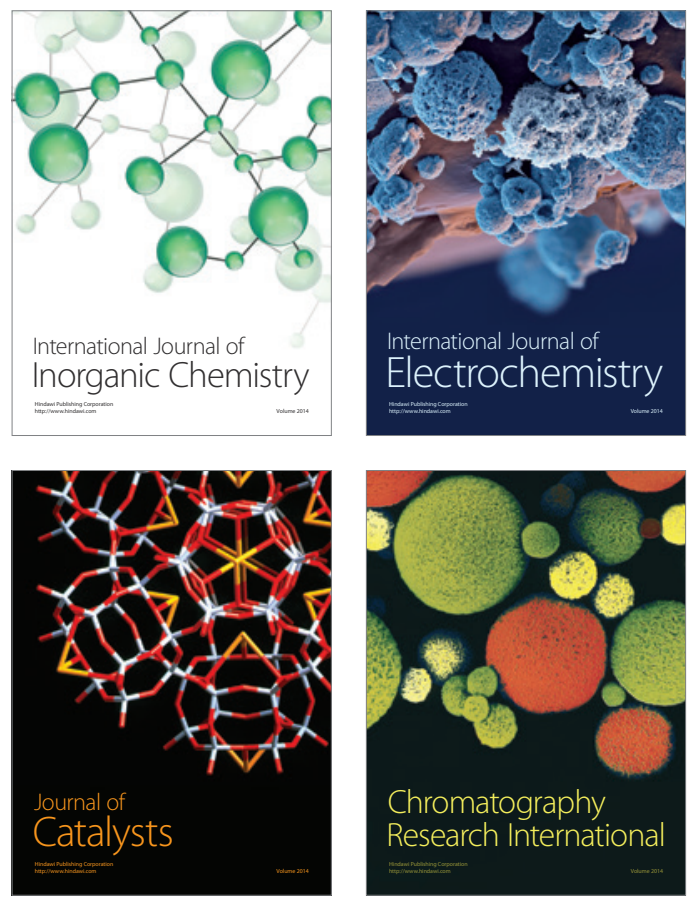
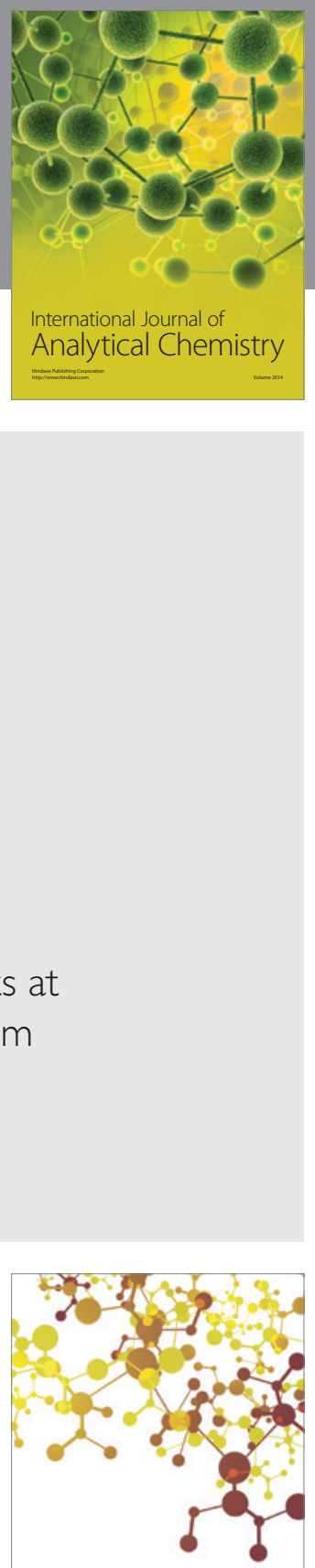

Journal of

Applied Chemistry
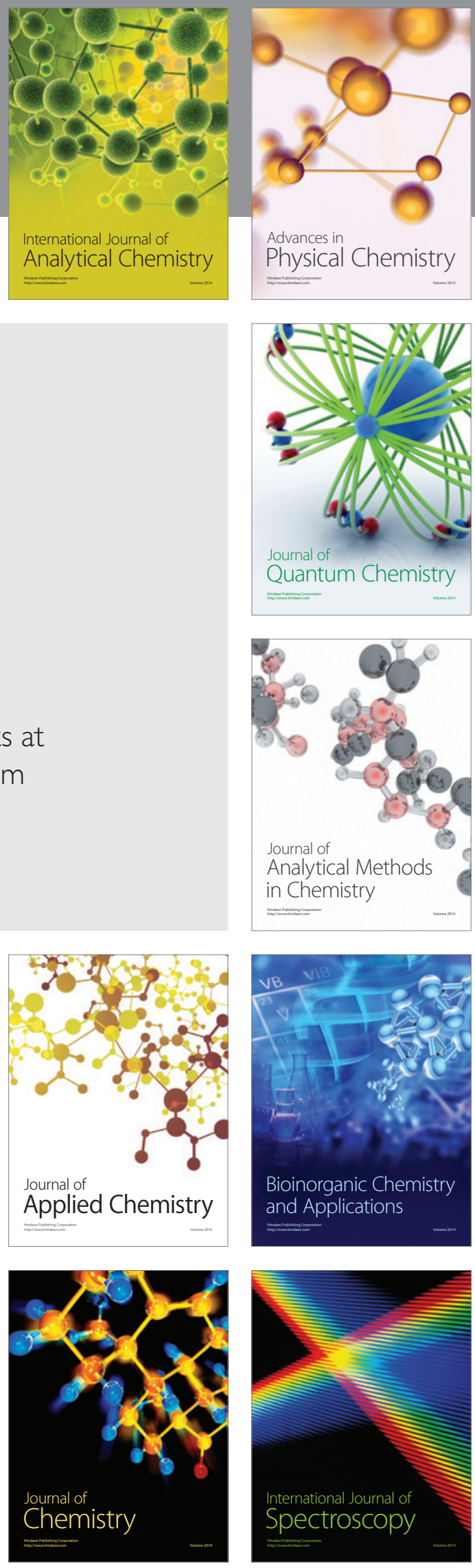